\title{
The Relationship between Total Calvarial Thickness and Diploe in the Elderly
}

\author{
Relación entre el Espesor Total de la Calvaria y Diploe en Ancianos
}

\author{
Vedat Sabanciogullari*; Ismail Salk** \& Mehmet Cimen*
}

\begin{abstract}
SABANCIOGULLARI, V.; SALK, I. \& CIMEN, M. The relationship between total calvarial thickness and diploe in the elderly. Int. J. Morphol., 31(1):38-44, 2013.

SUMMARY: The aim of this study is the classification of the thickness of diploe, lamina externa, lamina interna and total calvarial thickness at different points of cranium in elderly men and women. In the radiology archive, measurements were made at different points in cranial MR images of 220 (110 females, 110 males) patients, the average ages of whom were $73.23 \pm 8.40$ (age range: 61-90) and who had no disorder of the bones. Diploe thickness, lamina externa, lamina interna and total calvarial thickness were measured in eight points of the calvaria. Midfrontal point, back and front bregma, lambda, opisthocranion and euryon points were used in the measurement. The data was loaded to SPSS 16.0 program. T-test, Mann-Whitney U, Pearson correlation coefficient and Kruskal Wallis variance analysis were used in the statistical assessment. Results with a p value smaller than 0.05 were accepted as significant. There was statistically significant difference in total cranial thickness between males and females in the right euryon point only. Average total calvarial thickness at right euryon point was higher in females $(6.20 \pm 0.78 \mathrm{~mm})$ than in males $(5.96 \pm 0.68 \mathrm{~mm})(\mathrm{p}=0.02)$. Average diploe thickness was higher in female than male except for point of bregma back $(\mathrm{p}<0.05)$. There was positive linear correlation between diploe thickness and age except for opisthocranion, right euryon and $1 \mathrm{~cm}$ inferior to lambda. These results related to diploe thickness and cranium thickness may be leading in the determination of sex and age; surgical interventions to the cranium and bone graft choice and may increase the reliability of the operation.
\end{abstract}

KEYWORDS: Diploe thickness; Anthropologic points; Lamina interna; Lamina externa; MRI.

\section{INTRODUCTION}

In reconstruction of maxillafacial bone defect, the use of calvarial bone grafts is common. However, as lamina interna and dura damnification may occur, there are some hesitations for extracting the bone grafts in elderly patients (Hwang et al., 2000).

Used in "cervical spine" stabilization, "the halo pin" may sometimes cause serious complications, especially in individuals over 70 years old, such as brain damage, hematoma and infection by passing into the intracranial cavity. Therefore, the search of safe "halo pin" practicing areas is ongoing (Ebraheim et al., 2007).

Besides the researchers putting forward that morphologic and morphometric changes occur with aging in cranium, there are some other researchers claiming that diploic composition does not change (Hwang et al.; Skrzat et al., 2004; Sullivan \& Smith, 1989; Ross et al., 1998).
In addition, using diploe and total cranial thickness in age and sex determination is a different matter of debate. As well as those claiming these parameters differ in women and men and can be used in forensic medicine and anthropology for identification, there are some others claiming the exact opposite (Lynnerup, 2001; Hatipoglu et al., 2008).

So, the change of these parameters in elderly was examined by measuring total cranial thickness, lamina externa, lamina interna and diploe thickness from different anthropological points in a wide sample group.

\section{MATERIAL AND METHOD}

Study population. In the radiology archive, measurements were made at different points in MR images of 220 (110 females, 110 males) patients, the average ages of whom were $73.23 \pm 8.40$ (age range: 61-90) and who had no disorder of the cranial bones. 
The average ages of female were $72.90 \pm 8.45$ (age range: 61-91) while the average ages of male 73.56 \pm 8.37 (age range: 61-90). All 220 patients underwent clinical MR imaging of the cranium at MRI Unit between January and December 2010. The study was approved by the Human Ethics Committee of Sivas Province, and all participants gave written informed consent.

MRI parameters. MRI was performed on a 1.5-T whole-body MR system (Magnetom Symphony, Siemens, Erlangen, Germany). Examination included T1-weighted fast spin-echo sagittal and axial images with effective echo time and repetition times (TE/TR) of 11/ $434 \mathrm{~ms}$. A field of view (FOV) of $216 \mathrm{~mm} \times 240 \mathrm{~mm}$, matrix of 192 X112 matrix and $5.0 \mathrm{~mm}$ sections were used.

Image analysis. Thickness of diploe, lamina interna, lamina externa and total calvarial thickness were measured on the sagittal and axial T1-weighted images according to below anthropological points (Hatipoglu et al.).

Nasion: The middle point of the nasofrontal suture.

Bregma: It is located at the intersection point of the coronal suture and the sagittal suture.

Lambda: It is located at the intersection point of the sagittal suture and the lambdoid suture.

Opisthocranion: The most prominent posterior point on the occiput.

Euryon: The most prominent lateral points on the either parietal bones.

Points of measurement of diploe thickness, lamina externa, lamina interna, total calvarial thickness (Figs. 1A, 1B and 2).

Point 1 (P1): Midfrontal point, at the midpoint of the direct distance from nasion (n) to bregma (b) taken in the midsagittal plane.

Point 2 (P2): $1 \mathrm{~cm}$ anterior to bregma

Point 3 (P3): $1 \mathrm{~cm}$ posterior to bregma

Point 4 (P4): $1 \mathrm{~cm}$ superior to lambda

Point 5 (P5): $1 \mathrm{~cm}$ inferior to lambda

Point 6 (P6): Opisthocranion

Point 7 (P7): Right euryon

Point 8 (P8): Left euryon

Statistical analysis. The data was loaded to SPSS 16.0 programme. T-test, Mann-Whitney U, Pearson correlation coefficient and Kruskal Wallis variance analysis were used in the statistical assessment. Results with a $\mathrm{p}$ value smaller than 0.05 were accepted as significant.
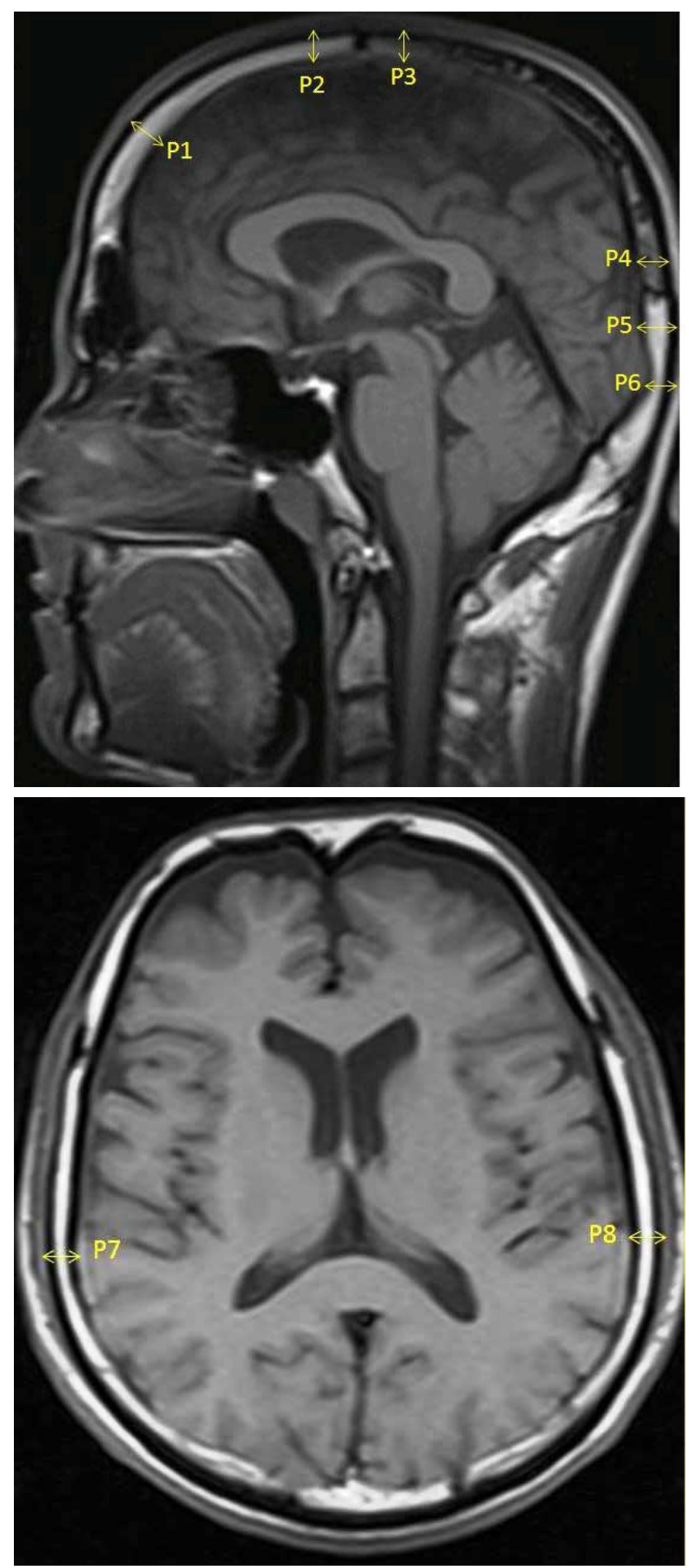

Fig. 1. A) Points of measurement of diploe thickness, lamina externa, lamina interna, total calvarial thickness, P1: Midfrontal point, P2: 1 $\mathrm{cm}$ anterior to bregma, $\mathrm{P} 3: 1 \mathrm{~cm}$ posterior to bregma, $\mathrm{P} 4: 1 \mathrm{~cm}$ superior to lambda, P5: 1cm inferior to lambda, P6: Opisthocranion. B) P7: Right euryon, P8: Left euryon. 


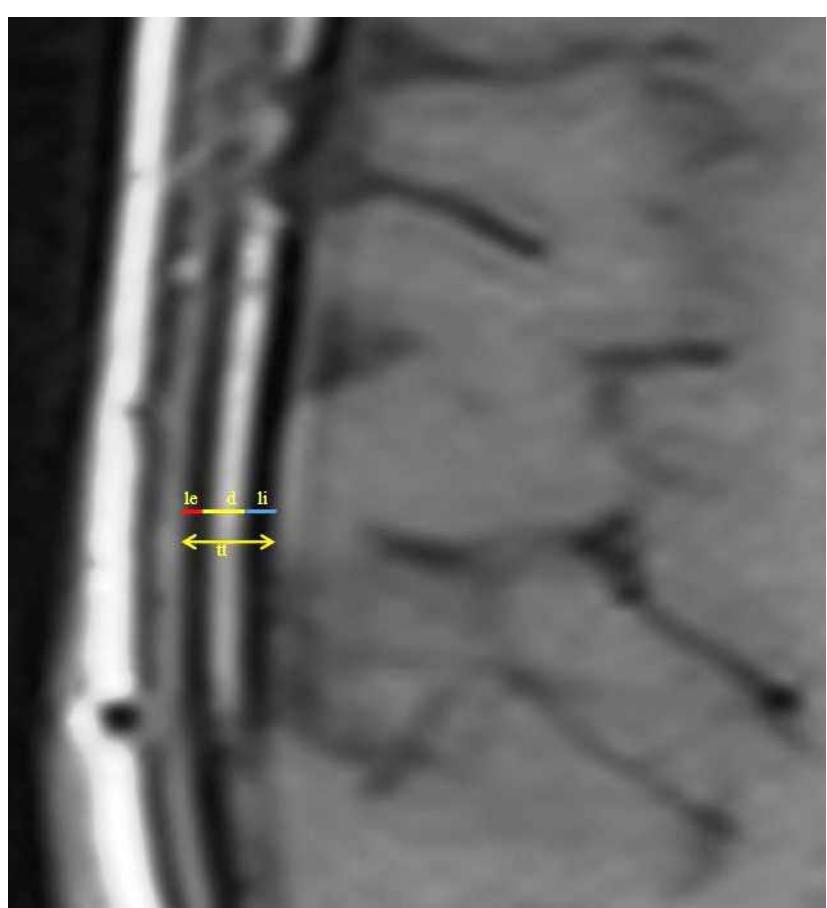

Fig. 2. A magnified cross section view of the measurements made from each point. le: lamina externa, li: lamina interna, tt: total calvarial thickness, d: diploe thickness.

\section{RESULTS}

While lamina interna and externa in frontal bone midline were thicker in men, diploe thickness was higher in women ( $\mathrm{p}<0.05)$. In parietal bone midline in men, lamina interna was thicker on the front, both lamina interna and lamina externa was thicker at the back. The diploe thickness measured in the near point to lambda was higher in women $(\mathrm{p}<0.05)$ (Table I).

While both diploe and cranium thickness in euryon points located in laterals of parietal bones are high in women, lamina interna in left euryon point is thicker in men $(p<0.05)$ (Table I).

Lamina externa thickness in P5 and P6 points in occipital bone was determined to be higher in men and diploe thickness was noticeably higher in women $(\mathrm{p}<0.05)($ Table I).

In $\mathrm{P} 1$ point, diploe thickness was increased depending on age in women $(p=0.034)$. Total thickness is also increasing in women together with age in parallel with increase in diploe thickness. In P2 point, there has been an increase in diploe $(p=0.048)$ and total thickness depending on age in women. In $\mathrm{P} 3$ point (bregma $1 \mathrm{~cm}$ back), total cranial thickness noticeably increased with age depending on the increase in diploe $(\mathrm{p}=0.000)$. In P4 point, although lamina externa thickness decreased in elderly, lamina interna, diploe and total cranial thickness remarkably increased $(p=0.000)$. In P6 (opisthocranion) point in women, lamina externa is getting thinner with age $(\mathrm{p}=0.033)$. In left euryon point (P8), diploe and cranial thickness increased with age $(\mathrm{p}=0.001)$ (Table II).

Diploe thickness was increasing with age except for opisthocranion, right euryon and P5 points $(\mathrm{p}<0.05)$. Lamina externa thickness was decreasing depending on age except for $\mathrm{P} 2$ and $\mathrm{P} 3$ points. The decrease in thickness in opisthocranion and $\mathrm{P} 4$ points was statistically significant $(\mathrm{p}<0.05)$ (Table III).

\section{DISCUSSION}

It was reported that calvarial grafts taken from parts very close to sutura sagitallis may cause, if not careful, cerebral cortex, sinus sagitallis superior or arachnoid granulation lacerations, subdural hematoma, permanent neurological deficits or even death. It was determined that these complications were not so low as it was supposed and the rate rose up to \%15 (Moreira-Gonzalez et al., 2006; Kline $\&$ Wolfe, 1990).

Therefore, choosing the safe area during graft harvesting is important in terms of preventing possible complications and increasing the safe of operation. MoreiraGonzalez et al., offered the rear outer area of parietal bone in women and parasagittal rear area in men as the most suitable and safest area for calvarial graft harvesting. They reported that, in these areas, calvarial thickness $(6.8-7.0 \mathrm{~mm})$ was over the average $(6.32 \pm 1.45 \mathrm{~mm})$ and these parts have aesthetical advantage.

In our study, in euryon points located in parietal bone lateral (P7 and P8), while average cranial thickness was 6.08 $\pm 0.74 \mathrm{~mm}$ on the right and $6.22 \pm 0.83 \mathrm{~mm}$ on the left; in the mid-sagittal line, it was $5.62 \pm 1.05 \mathrm{~mm}$ on the front (P3) and $7.56 \pm 1.44 \mathrm{~mm}$ at the back (P4) (Table I). According to these results, for calvarial bone grafts, as MoreiraGonzalez et al., reported, the back half of the parietal bone which is thicker and near to sutura lambdoidea may primarily be preferred and possible complications may be minimized.

Sullivan \& Smith measured the parietal and occipital bone thickness in craniums belonging to cadavers between 59-96 years old from two different points they determined. They found lamina externa thickness of parietal bone as 1.7 


\begin{tabular}{|c|c|c|c|c|c|}
\hline Point of Measuring & $\begin{array}{c}\text { Female (F) } \\
(\mathbf{n}=110) \\
\text { Mean } \pm \\
\text { SD } \\
(\mathbf{m m})\end{array}$ & $\begin{array}{c}\text { Male }(M) \\
(\mathbf{n}=110) \\
\text { Mean } \pm \\
\text { SD } \\
(\mathbf{m m})\end{array}$ & $\begin{array}{c}\text { Total } \\
(\mathbf{n}=\mathbf{2 2 0}) \\
\text { Mean } \pm \\
\text { SD } \\
(\mathbf{m m})\end{array}$ & $\begin{array}{c}\text { Test } \\
\text { (t-test) }\end{array}$ & $\mathbf{P}$ \\
\hline P1 LE & $1.22 \pm 0.19$ & $1.44 \pm 0.28$ & $1.33 \pm 0.26$ & 6.549 & 0.000 \\
\hline P1 D & $5.32 \pm 1.72$ & $4.81 \pm 1.26$ & $5.06 \pm 1.52$ & 2.501 & 0.013 \\
\hline P1 LI & $1.24 \pm 0.22$ & $1.33 \pm 0.16$ & $1.28 \pm 0.20$ & 3.387 & 0.001 \\
\hline $\mathrm{P} 1 \mathrm{TT}$ & $7.79 \pm 1.82$ & $7.59 \pm 1.37$ & $7.69 \pm 1.61$ & 0.923 & 0.357 \\
\hline P2 LE & $1.20 \pm 0.19$ & $1.30 \pm 026$ & $1.25 \pm 0.23$ & 3.276 & 0.001 \\
\hline P2D & $3.55 \pm 0.95$ & $3.17 \pm 0.84$ & $3.36 \pm 0.91$ & 3.153 & 0.002 \\
\hline P2 LI & $1.16 \pm 0.17$ & $1.26 \pm 0.18$ & $1.21 \pm 0.18$ & 4.345 & 0.000 \\
\hline P2 TT & $5.92 \pm 0.98$ & $5.74 \pm 0.97$ & $5.83 \pm 0.97$ & 1.325 & 0.187 \\
\hline P3LE & $1.17 \pm 0.18$ & $1.21 \pm 0.22$ & $1.19 \pm 0.20$ & 1.469 & 0.143 \\
\hline P3 D & $3.26 \pm 0.93$ & $3.28 \pm 1.01$ & $3.27 \pm 0.97$ & 0.152 & 0.879 \\
\hline P3 LI & $1.12 \pm 0.17$ & $1.19 \pm 0.19$ & $1.15 \pm 0.18$ & 2.797 & 0.006 \\
\hline P3 TT & $5.55 \pm 0.98$ & $5.68 \pm 1.13$ & $5.62 \pm 1.05$ & 0.911 & 0.363 \\
\hline P4 LE & $1.46 \pm 0.24$ & $1.74 \pm 0.46$ & $1.60 \pm 0.39$ & 5.428 & 0.000 \\
\hline P4 D & $4.81 \pm 1.33$ & $4.45 \pm 1.13$ & $4.63 \pm 1.24$ & 2.131 & 0.034 \\
\hline P4 LI & $1.26 \pm 0.21$ & $1.38 \pm 0.24$ & $1.32 \pm 0.23$ & 3.921 & 0.000 \\
\hline P4 TT & $7.54 \pm 1.49$ & $7.58 \pm 1.41$ & $7.56 \pm 1.44$ & 0.205 & 0.838 \\
\hline P 5LE & $1.42 \pm 0.27$ & $1.61 \pm 0.30$ & $1.51 \pm 0.30$ & 5.007 & 0.000 \\
\hline P5 D & $5.45 \pm 1.40$ & $4.87 \pm 1.19$ & $5.16 \pm 1.33$ & 3.320 & 0.001 \\
\hline P 5LI & $1.26 \pm 0.20$ & $1.28 \pm 0.21$ & $1.27 \pm 0.21$ & 0.638 & 0.524 \\
\hline P 5TT & $8.14 \pm 1.46$ & $7.77 \pm 1.41$ & $7.95 \pm 1.44$ & 1.906 & 0.058 \\
\hline P6 LE & $1.42 \pm 0.27$ & $1.57 \pm 0.28$ & $1.49 \pm 0.28$ & 3.913 & 0.000 \\
\hline P6 D & $5.85 \pm 1.76$ & $5.32 \pm 1.71$ & $5.58 \pm 1.75$ & 2.271 & 0.024 \\
\hline P6 LI & $1.29 \pm 0.18$ & $1.31 \pm 0.19$ & $1.30 \pm 0.19$ & 0.773 & 0.441 \\
\hline P6TT & $8.57 \pm 1.86$ & $8.20 \pm 1.81$ & $8.38 \pm 1.84$ & 1.476 & 0.141 \\
\hline P7 LE & $1.42 \pm 0.20$ & $1.37 \pm 0.23$ & $1.39 \pm 0.22$ & 1.561 & 0.120 \\
\hline P7 D & $3.46 \pm 0.71$ & $3.27 \pm 0.53$ & $3.37 \pm 0.63$ & 2.256 & 0.025 \\
\hline P7 LI & $1.30 \pm 0.17$ & $1.31 \pm 0.16$ & $1.31 \pm 0.17$ & 0.235 & 0.815 \\
\hline P7 TT & $6.20 \pm 0.78$ & $5.96 \pm 0.68$ & $6.08 \pm 0.74$ & 2.350 & 0.020 \\
\hline P8 LE & $1.30 \pm 0.21$ & $1.35 \pm 0.18$ & $1.32 \pm 0.20$ & 1.506 & 0.133 \\
\hline P8 D & $3.69 \pm 0.81$ & $3.42 \pm 0.64$ & $3.55 \pm 0.74$ & 2.695 & 0.008 \\
\hline P8 L_ & $1.29 \pm 0.20$ & $1.37 \pm 0.20$ & $1.33 \pm 0.20$ & 2.568 & 0.011 \\
\hline P8 TT & $6.30 \pm 0.90$ & $6.14 \pm 0.74$ & $6.22 \pm 0.83$ & 1.383 & 0.168 \\
\hline
\end{tabular}

D:Diploe thickness; LE:Lamina externa; LI:Lamina interna; TT:Total calvarial thickness

$\pm 0.3 \mathrm{~mm}$ and total calvarial thickness as $6.4 \pm 1.8 \mathrm{~mm}$. They reported that lamina externa and diploe thickness of parietal bone do not change depending on age, but lamina interna and total calvarial bone show negative correlation. Thus, they reported that split parietal grafts may easily be used in elderly patients.
In our study, we did not observe any statistically significant change depending on age except for $\mathrm{P} 4$ point in lamina externa thickness of parietal bone, similar to Sullivan and Smith's findings. In P4 point that is near to rear end of sagittal suture, lamina externa was getting thinner together with advanced age in both women and men (Tables II and 
Table II. Comparing all measurement evaluations by age groups.

\begin{tabular}{|c|c|c|c|c|c|c|}
\hline \multirow{2}{*}{$\begin{array}{l}\text { Point of } \\
\text { Measuring }\end{array}$} & \multicolumn{2}{|c|}{ Group I $(n=92)$} & \multicolumn{2}{|c|}{ Group II (n=80) } & \multicolumn{2}{|c|}{ Group III $(n=48)$} \\
\hline & Female & Male $(n=44)$ & Female & Male $(n=38)$ & Female & Male \\
\hline P1 LE & $1.26 \pm 0.22$ & $1.46 \pm 0.35$ & $1.21 \pm 0.18$ & $1.44 \pm 0.25$ & $1.18 \pm 0.11$ & $1.41 \pm 0.22$ \\
\hline P1 D & $4.83 \pm 1.95$ & $4.81 \pm 1.49$ & $5.57 \pm 1.45$ & $4.71 \pm 1.09$ & $5.96 \pm 1.36$ & $4.93 \pm 1.09$ \\
\hline P1 LI & $1.28 \pm 0.20$ & $1.36 \pm 0.14$ & $1.20 \pm 0.27$ & $1.32 \pm 0.19$ & $1.23 \pm 0.15$ & $1.30 \pm 0.13$ \\
\hline P1 TT & $7.37 \pm 2.14$ & $7.64 \pm 1.64$ & $7.99 \pm 1.55$ & $7.48 \pm 1.25$ & $8.38 \pm 1.30$ & $7.65 \pm 1.07$ \\
\hline P2 LE & $1.23 \pm 0.22$ & $1.32 \pm 0.27$ & $1.18 \pm 0.17$ & $1.27 \pm 0.24$ & $1.19 \pm 0.12$ & $1.32 \pm 0.27$ \\
\hline P2D & $3.27 \pm 0.74$ & $2.94 \pm 0.81$ & $3.72 \pm 1.18$ & $3.44 \pm 0.92$ & $3.86 \pm 0.64$ & $3.15 \pm 0.67$ \\
\hline P2 LI & $1.16 \pm 0.14$ & $1.26 \pm 0.19$ & $1.14 \pm 0.18$ & $1.26 \pm 0.18$ & $1.19 \pm 0.23$ & $1.27 \pm 0.15$ \\
\hline P2 TT & $5.66 \pm 0.78$ & $5.53 \pm 0.96$ & $6.06 \pm 1.21$ & $5.99 \pm 1.07$ & $6.25 \pm 0.70$ & $5.75 \pm 0.77$ \\
\hline P3LE & $1.17 \pm 0.20$ & $1.22 \pm 0.26$ & $1.16 \pm 0.18$ & $1.17 \pm 0.22$ & $1.16 \pm 0.13$ & $1.24 \pm 0.15$ \\
\hline P3 D & $2.80 \pm 0.77$ & $2.80 \pm 0.89$ & $3.33 \pm 0.79$ & $3.29 \pm 0.68$ & $4.24 \pm 0.78$ & $4.03 \pm 1.11$ \\
\hline P3 LI & $1.11 \pm 0.14$ & $1.16 \pm 0.20$ & $1.11 \pm 0.22$ & $1.21 \pm 0.18$ & $1.15 \pm 0.09$ & $1.20 \pm 0.18$ \\
\hline P3 TT & $5.09 \pm 0.78$ & $5.18 \pm 1.03$ & $5.61 \pm 0.91$ & $5.68 \pm 0.81$ & $6.56 \pm 0.76$ & $6.48 \pm 1.22$ \\
\hline P4 LE & $1.51 \pm 0.23$ & $1.79 \pm 0.59$ & $1.48 \pm 0.22$ & $1.77 \pm 0.41$ & $1.32 \pm 0.27$ & $1.61 \pm 0.25$ \\
\hline P4 D & $4.50 \pm 1.47$ & $4.08 \pm 1.21$ & $4.75 \pm 1.24$ & $4.85 \pm 0.93$ & $5.67 \pm 0.60$ & $4.51 \pm 1.10$ \\
\hline P4 LI & $1.21 \pm 0.16$ & $1.35 \pm 0.26$ & $1.24 \pm 0.25$ & $1.38 \pm 0.22$ & $1.43 \pm 0.18$ & $1.44 \pm 0.21$ \\
\hline P4 TT & $7.23 \pm 1.58$ & $7.22 \pm 1.67$ & $7.48 \pm 1.49$ & $8.01 \pm 1.06$ & $8.43 \pm 0.74$ & $7.56 \pm 1.24$ \\
\hline P 5LE & $1.44 \pm 0.26$ & $1.70 \pm 0.35$ & $1.32 \pm 0.25$ & $1.53 \pm 0.30$ & $1.57 \pm 0.24$ & $1.58 \pm 0.16$ \\
\hline P5 D & $5.07 \pm 1.53$ & $4.72 \pm 1.25$ & $5.89 \pm 1.25$ & $4.96 \pm 1.18$ & $5.43 \pm 1.13$ & $4.98 \pm 1.22$ \\
\hline P 5LI & $1.23 \pm 0.19$ & $1.29 \pm 0.23$ & $1.26 \pm 0.22$ & $1.29 \pm 0.24$ & $1.36 \pm 0.16$ & $1.26 \pm 0.16$ \\
\hline P 5TT & $7.75 \pm 1.64$ & $7.72 \pm 1.54$ & $8.48 \pm 1.31$ & $7.78 \pm 1.40$ & $8.37 \pm 1.11$ & $7.83 \pm 1.21$ \\
\hline P6 LE & $1.50 \pm 0.30$ & $1.56 \pm 0.28$ & $1.38 \pm 0.23$ & $1.56 \pm 0.30$ & $1.32 \pm 0.23$ & $1.57 \pm 0.25$ \\
\hline P6 D & $5.61 \pm 1.87$ & $4.77 \pm 1.26$ & $6.15 \pm 1.81$ & $5.92 \pm 1.74$ & $5.80 \pm 1.29$ & $5.36 \pm 2.02$ \\
\hline P6 LI & $1.29 \pm 0.22$ & $1.31 \pm 0.18$ & $1.29 \pm 0.17$ & $1.30 \pm 0.19$ & $1.27 \pm 0.14$ & $1.32 \pm 0.22$ \\
\hline P6TT & $8.41 \pm 2.07$ & $7.66 \pm 1.35$ & $8.83 \pm 1.78$ & $8.79 \pm 1.86$ & $8.39 \pm 1.42$ & $8.26 \pm 2.14$ \\
\hline P7 LE & $1.45 \pm 0.22$ & $1.42 \pm 0.23$ & $1.38 \pm 0.19$ & $1.32 \pm 0.26$ & $1.43 \pm 0.18$ & $1.36 \pm 0.18$ \\
\hline P7 D & $3.31 \pm 0.51$ & $3.14 \pm 0.60$ & $3.74 \pm 0.88$ & $3.31 \pm 0.58$ & $3.25 \pm 0.55$ & $3.43 \pm 0.24$ \\
\hline P7 LI & $1.31 \pm 0.19$ & $1.30 \pm 0.20$ & $1.29 \pm 0.18$ & $1.29 \pm 0.13$ & $1.33 \pm 0.14$ & $1.35 \pm 0.12$ \\
\hline P7 TT & $6.08 \pm 0.67$ & $5.87 \pm 0.76$ & $6.42 \pm 0.93$ & $5.92 \pm 0.78$ & $6.01 \pm 0.56$ & $6.15 \pm 0.27$ \\
\hline P8 LE & $1.31 \pm 0.24$ & $1.35 \pm 0.20$ & $1.31 \pm 0.21$ & $1.34 \pm 0.19$ & $1.29 \pm 0.18$ & $1.34 \pm 0.13$ \\
\hline P8 D & $3.38 \pm 0.73$ & $3.28 \pm 0.55$ & $4.00 \pm 0.85$ & $3.58 \pm 0.74$ & $3.78 \pm 0.65$ & $3.43 \pm 0.58$ \\
\hline P8 LI & $1.27 \pm 0.20$ & $1.36 \pm 0.17$ & $1.30 \pm 0.21$ & $1.36 \pm 0.22$ & $1.34 \pm 0.21$ & $1.38 \pm 0.20$ \\
\hline P8 TT & $5.96 \pm 0.89$ & $6.00 \pm 0.68$ & $6.62 \pm 0.88$ & $6.29 \pm 0.89$ & $6.42 \pm 0.71$ & $6.16 \pm 0.59$ \\
\hline
\end{tabular}

D:Diploe thickness; LE:Lamina externa; LI:Lamina interna; TT:Total calvarial thickness

III). That's why, for split calvarial grafts to be taken from elderly patients, posterolateral area of parietal bone seems to be safer than areas that are too close to sutura sagittalis.

Hwang et al., measured parietal bone thickness in cadavers belonging to 49 Korean and 30 white individuals between 4-99 years old. In their measurements in posteromedial part of parietal bone, they found total thickness and lamina externa thickness as $6.85 \pm 1.6 \mathrm{~mm}$ and $1.89 \pm 0.7 \mathrm{~mm}$ in 60-79 age group, $7.06 \pm 1.6 \mathrm{~mm}$ and $1.95 \pm 0.8 \mathrm{~mm}$ in above 80 years old, respectively. Depending upon their findings, they put forward that lamina externa, lamina interna, diploe and total thickness of parietal bone do not show any statistically significant differences between age groups therefore surgeons may use parietal bone lamina externa in elderly patients without any hesitation. They also suggested posteromedial part of parietal bone as the safe area. 
Table III The correlation between age and diploe thickness (D) and lamina externa (LE), lamina interna (LI), total calvarial thickness (TT).

\begin{tabular}{lccc}
\hline Point of & $\begin{array}{c}\text { Total }(\mathbf{n}=\mathbf{2 2 0}) \\
\text { Measuring } \\
(\mathbf{m m})\end{array}$ & $\begin{array}{c}\text { Pearson } \\
\text { correlation } \\
(\mathbf{r})\end{array}$ & $\mathbf{P}$ \\
\hline P1 LE & $1.33 \pm 0.26$ & -0.099 & 0.145 \\
P1 D & $5.06 \pm 1.52$ & 0.151 & $0.025^{*}$ \\
P1 LI & $1.28 \pm 0.20$ & -0.154 & $0.022^{*}$ \\
P1 TT & $7.69 \pm 1.61$ & 0.107 & 0.113 \\
P2 LE & $1.25 \pm 0.23$ & 0.018 & 0.794 \\
P2D & $3.36 \pm 0.91$ & 0.199 & $0.003^{* *}$ \\
P2 LI & $1.21 \pm 0.18$ & 0.043 & 0.531 \\
P2 TT & $5.83 \pm 0.97$ & 0.198 & $0.003^{* *}$ \\
P3LE & $1.19 \pm 0.20$ & 0.020 & 0.772 \\
P3 D & $3.27 \pm 0.97$ & 0.535 & $0.000^{* *}$ \\
P3 LI & $1.15 \pm 0.18$ & 0.086 & 0.204 \\
P3 TT & $5.62 \pm 1.05$ & 0.510 & $0.000^{* *}$ \\
P4 LE & $1.60 \pm 0.39$ & -0.175 & $0.009^{* *}$ \\
P4 D & $4.63 \pm 1.24$ & 0.250 & $0.000^{* *}$ \\
P4 LI & $1.32 \pm 0.23$ & 0.221 & $0.001^{* *}$ \\
P4 TT & $7.56 \pm 1.44$ & 0.204 & $0.002^{* *}$ \\
P 5LE & $1.51 \pm 0.30$ & -0.057 & 0.399 \\
P5 D & $5.16 \pm 1.33$ & 0.125 & 0.064 \\
P 5L_ & $1.27 \pm 0.21$ & 0.091 & 0.181 \\
P 5TT & $7.95 \pm 1.44$ & 0.116 & 0.086 \\
P6 LE & $1.49 \pm 0.28$ & -0.134 & $0.047^{*}$ \\
P6 D & $5.58 \pm 1.75$ & 0.103 & 0.126 \\
P6 LI & $1.30 \pm 0.19$ & -0.062 & 0.360 \\
P6TT & $8.38 \pm 1.84$ & 0.071 & 0.293 \\
P7 LE & $1.39 \pm 0.22$ & -0.124 & 0.067 \\
P7 D & $3.37 \pm 0.63$ & 0.100 & 0.139 \\
P7 LI & $1.31 \pm 0.17$ & 0.039 & 0.567 \\
P7 TT & $6.08 \pm 0.74$ & 0.058 & 0.392 \\
P8 LE & $1.32 \pm 0.20$ & -0.056 & 0.413 \\
P8 D & $3.55 \pm 0.74$ & 0.193 & $0.004^{* *}$ \\
P* LI & $1.33 \pm 0.20$ & 0.029 & 0.673 \\
P6 & $6.22 \pm 0.83$ & 0.167 & $0.013^{*}$ \\
\hline
\end{tabular}

** Correlation is significant at the 0.01 level (2-tailed).

* Correlation is significant at the 0.05 level (2-tailed).

In our study, except for right euryon point (P7), thickening in parietal bone together with increased age $(\mathrm{p}<0.05)$ and therefore increase in total thickness was determined. In our measurements from parietal bone, while LE was getting thinner only in $\mathrm{P} 4$ point, $\mathrm{LI}^{*}$ was thickening ( $<<0.05$; Table II and III). That lamina externa thickness does not change and on the contrary diploe thickens shows that parietal bone is a good reservoir for split calvarial graft even in advanced ages.

The research results analyzing the relationship between cranium thickness and sex are contradictory, as well (Hwang et al.; Ross et al.; Lynnerup; Ishida \& Dodo, 1990; Smith et al., 1985; Getz, 1960). Hwang et al., found the average parietal bone thickness to be $7.31 \pm 1.6 \mathrm{~mm}$ in women, $6.43 \pm 1.6 \mathrm{~mm}$ in men, and average lamina externa thickness to be $2.01 \pm 0.7 \mathrm{~mm}$ in women, $1.86 \pm 0.7$ in men. Depending on their findings, they claimed that parietal bone is getting thicker in elderly, lamina externa and total thickness are higher in women, but the change in LE is statistically unimportant. Ishida \& Dodo emphasized that cranial thickness is higher in men in Neolithic Jomon society than in today's Japanese people. The cranium thickness in frontal and parietal area is higher in women among today's Japanese people, as well. Smith et al., carried out some measurements on 111 craniums belonging to people who lived in Israel and Jordan in the past 12,000 years. Depending on their findings, they reported that cranial thickness does not show statistically significant difference between the sexes. Ross et al., set forth that there is no thickness difference between woman and man craniums except for hyperostosis frontalis interna beginning. Similarly, Getz did not find sexual dimorphism in cranial thickness. Lynnerup indicated that there is no cranial thickness difference between women and men, except for right euryon point. He detected the average cranial thickness on the right euryon to be $5.635 \pm 1.138 \mathrm{~mm}$ in women, $5.040 \pm 1.250 \mathrm{~mm}$ in men $(\mathrm{p}=0.031)$.

In this study, cranium thickness was measured from eight different points. Compatible with Lynnerup results, total cranial thickness showed statistically significant difference only in right euryon point between women and men. At this point, cranial thickness was $5.96 \pm 0.68 \mathrm{~mm}$ in men while it was $6.20 \pm 0.78$ $\mathrm{mm}$ in women, $(\mathrm{p}=0.020$, Table I). According to this result, parietal bone thickness is almost the same near the sagittal suture in both sexes whereas it was higher in parietal bone lateral parts in women. This difference especially arises from thickening of the diploe (Table I). Similarly, Moreira-Gonzalez et al., found the average cranium thickness higher in women than in men. They determined that difference between reaches up to $5 \mathrm{~mm}$ especially in parietal bones. Lynnerup et al., (2005) carried out measurements in biopsies taken from four different points in frontal, parietal and occipital bones in calvariums of autopsied 43 men and 21 women. They claimed that men have thicker diploe, this difference is statistically significant only in frontal area, and the age has no effect on diploe thickness. They also found high correlation between total cranial thickness and diploe thickness.

In all points we measured, there was positive linear correlation between diploe and total cranial thickness. However, 
unlike Lynnerup et al., findings, in all points except for occipital bone and right euryon point, diploe thickness was increasing depending on age, and women had thicker diploe than men, except for P3 point ( $\mathrm{p}<0.05$, Table I and III).

As a result, there is a specific increase especially in frontal and parietal bone diploe thickness in both women and men in advanced age. Total cranial thickness is also increasing in parallel with increase in diploe thickness. Total cranial thickness shows statistically significant difference only in right euryon point between women and men. The thickness of lamina externa used as split calvarial graft does not change except for $\mathrm{P} 4$ and $\mathrm{P} 6$ points. Therefore, even in advanced ages, especially posterolateral area of parietal bone may be preferred in graft extraction. Obtained from a wide sample group, this information may be used in age and sex determination, as well.

SABANCIOGUllaRI, V.; SALK, I. \& CIMEN, M. Relación entre el espesor total de la calvaria y diploe en ancianos. Int. J. Morphol., 31(1):38-44, 2013.

RESUMEN: El objetivo de este estudio fue clasificar el espesor del diploe, láminas externa e interna y el espesor craneal total en diferentes puntos del cráneo en hombres y mujeres ancianos. Desde el archivo de radiología se obtuvieron imágenes de RM craneales de 220 pacientes (110

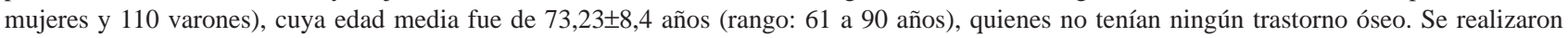
mediciones de espesor del diploe, láminas externa e interna, y el grosor de la bóveda craneal. Se utilizaron ocho puntos de la bóveda craneal en la medición: mediano frontal, bregma anterior y posterior, lambda superior e inferior, opistocranion y euryon derecho e izquierdo. Los datos fueron analizados mediante el programa SPSS 16.0. Para la evaluación estadística se utilizaron en las pruebas T-test, Mann-Whitney U, coeficiente de correlación de Pearson y Kruskal Wallis de análisis de varianza. Los resultados con un valor de p inferior a 0,05 se aceptaron como significativo. Sólo hubo diferencias estadísticamente significativas en el espesor total del cráneo entre hombres y mujeres en el punto euryon derecho. El promedio de espesor total de la bóveda craneal en el punto euryon derecho fue mayor en mujeres $(6,20 \pm 0,78 \mathrm{~mm})$ que hombres $(5,96 \pm 0,68 \mathrm{~mm})(\mathrm{p}=0,02)$. El promedio de espesor del diploe fue mayor en mujeres que hombres, excepto para el punto de bregma posterior ( $\mathrm{p}<0,05)$. Hubo una correlación lineal positiva entre el grosor diploe y edad, excepto para opistocranion, euryon derecho y $1 \mathrm{~cm}$ inferior a lambda. Estos resultados relacionados con el espesor del diploe y espesor craneal pueden ser relevantes para la determinación de sexo y edad; intervenciones quirúrgicas en el cráneo y la elección de injertos óseos, y puede aumentar la exactitud de la operación.

PALABRAS CLAVE: Espesores del diploe; Puntos antropológicos; Lámina interna; Lámina externa; RM.

\section{REFERENCES}

Ebraheim, N. A.; Liu, J.; Patil, V.; Sanford, C. G. Jr.; Crotty, M. J.; Haman, S. P. \& Yeasting, R. A. Evaluation of skull thickness and insertion torque at the halo pin insertion areas in the elderly: a cadaveric study. Spine J., 7(6):689-93, 2007.

Getz, B. Skull thickness in the frontal and parietal regions. Acta Morphol. Neerl. Scand., 3:221-8, 1960.

Hatipoglu, H. G.; Ozcan, H. N.; Hatipoglu, U. S. \& Yuksel, E. Age, sex and body mass index in relation to calvarial diploe thickness and craniometric data on MRI. Forensic Sci. Int., 182(1-3):4651,2008 .

Hwang, K.; Hollinger, J. O.; Chung, R. S. \& Lee, S. I. Histomorphometry of parietal bones versus age and race. $J$. Craniofac. Surg., 11(1):17-23, 2000.

Ishida, H. \& Dodo, Y. Cranial thickness of modern and neolithic populations in Japan. Hum Biol., 62(3):389-401, 1990.

Kline, R. M. Jr. \& Wolfe, S. A. Complications associated with the harvesting of cranial bone grafts. Plast. Reconstr. Surg., 95(1):513; discussion 14-20, 1995.

Lynnerup, N. Cranial thickness in relation to age, sex and general body build in a Danish forensic sample. Forensic Sci. Int., 117(12):45-51, 2001

Lynnerup, N.; Astrup, J. G. \& Sejrsen, B. Thickness of the human cranial diploe in relation to age, sex and general body build. Head Face Med., 1:13, 2005.

Moreira-Gonzalez, A.; Papay, F. E. \& Zins, J. E. Calvarial thickness and its relation to cranial bone harvest. Plast. Reconstr. Surg., 117(6):1964-71, 2006.

Ross, A. H.; Jantz, R. L. \& McCormick, W. F. Cranial thickness in American females and males. J. Forensic Sci., 43(2):267-72, 1998.

Skrzat, J.; Brzegowy, P.; Walocha, J. \& Wojciechowski, W. Age dependent changes of the diploe in the human skull. Folia Morphol. (Warsz), 63(1):67-70, 2004.

Smith, P.; Wax, Y.; Becker, A. \& Einy, S. Diachronic variation in cranial thickness of Near Eastern populations. Am. J. Phys. Anthropol., 67(2):127-33, 1985.

Sullivan, W. G. \& Smith, A. A. The split calvarial graft donor site in the elderly: a study in cadavers. Plast. Reconstr. Surg., 84(1):2931, 1989.

Correspondence to:

Assistant Prof. Dr. Vedat Sabanciogullari

Department of Anatomy

Cumhuriyet University School of Medicine

58140 Sivas

TURKEY

Email: vsabanci@yahoo.com.tr
Received: 09-05-2012

Accepted: 31-10-2012 